\title{
Kesehatan hidung siswa-siswi Sekolah Menengah Pertama Negeri 4 Pineleng
}

\author{
${ }^{1}$ Pebrianto A. Pakiding \\ ${ }^{2}$ Olivia C. P. Pelealu \\ ${ }^{2}$ Steward K. Mengko
}

\author{
${ }^{1}$ Kandidat Skripsi Fakultas Kedokteran Universitas Sam Ratulangi Manado \\ ${ }^{2}$ Bagian/SMF Telinga Hidung Tenggorokan-Bedah Kepala Leher Fakultas Kedokteran \\ Universitas Sam Ratulangi Manado \\ Email: pebriantoanugrah@gmail.com
}

\begin{abstract}
Environmental factors play some important roles in human health. Environmental changes influence the nose function. This study was aimed to obtain the nose health status of students at SMPN 4 (Junior High School) Pineleng. This was a descriptive observational study with a cross sectional design. Respondents were students of SMPN 4 Pineleng. There were 25 respondents consisted of 13 males and 12 females. The results of the examination showed normal nose health status in 18 students and abnormalities in 7 students. Examination of the nasal cavity revealed narrow nasal cavity $12 \%$. Examination of the concha revealed pale and hyperthrophy concha $8 \%$; hyperemia $4 \%$; hypertrophy $4 \%$ in the left nostril; and pale accompanied with edema and hypertrophy $4 \%$ on the right nostril. Examination of the mucosa showed the percentage of livide mucosa $12 \%$ in the right nostril and $8 \%$ in the left nostril; and hyperemia $4 \%$ in the left nostril. Examination of secretion showed serous secretion $12 \%$ in the right nostril and $8 \%$ in the left nostril. Examination of the septum showed septum deviation $4 \%$ in the left nostril meanwhile post nasal drip was found as many as 4\%. Conclusion: Most students of SMPN 4 Pineleng had good nasal health status.
\end{abstract}

Keywords: nose health, nose examination

\begin{abstract}
Abstrak: Lingkungan merupakan faktor terbesar yang memengaruhi kesehatan. Perubahan lingkungan memberikan pengaruh terhadap fungsi hidung. Penelitian ini bertujuan untuk mengetahui kesehatan hidung pada siswa-siswi SMPN 4 Pineleng. Jenis penelitian ialah deskriptif survei dengan desain potong lintang. Responden penelitian ialah siswa-siswi Sekolah Menengah Pertama Negeri 4 Pineleng. Terrdapat 25 responden yang mengikuti penelitian terdiri dari 13 laki-laki dan 12 perempuan. Pemeriksaan hidung mendapatkan hasil normal pada 18 responden dan kelainan pada 7 responden. Pada pemeriksaan kavum nasi kelainan yang ditemukan berupa kavum nasi sempit $12 \%$; konka pucat dan hipertrofi $8 \%$; hiperemis $4 \%$; hipertrofi $4 \%$ hidung kiri; edema disertai pucat dan hipertrofi $4 \%$ hidung kanan. Pemeriksaan mukosa livide $12 \%$ hidung kanan, dan $8 \%$ hidung kiri; hiperemis $4 \%$ hidung kiri. Pada pemeriksaan sekret, serous $12 \%$ hidung kanan dan $8 \%$ hidung kiri. Pada pemeriksaan septum, deviasi $4 \%$ hidung kiri. Persentase post nasal drip 4\%. Simpulan: Sebagian besar siswa-siswi SMPN 4 Pineleng mempunyai kesehatan hidung yang baik.
\end{abstract}

Kata kunci: kesehatan hidung, pemeriksaan hidung

Kesehatan merupakan keadaan fisik, kelemahan. ${ }^{1}$ Dalam UU Kesehatan No. 23 mental dan sosial yang baik, tidak hanya tahun 1992, kesehatan merupakan keadaan terbebas dari penyakit, cacat, atau sejahtera dari badan, jiwa dan sosial yang 
memungkinkan setiap orang hidup produktif. ${ }^{2}$ Kesehatan berperan besar dalam meningkatkan derajat hidup masyarakat agar dapat hidup produktif., ${ }^{2,3}$ Kesehatan merupakan hasil interaksi berbagai faktor, baik faktor internal maupun eksternal. Kesehatan merupakan totalitas dari faktor lingkungan, perilaku, pelayanan kesehatan, dan faktor keturunan yang saling memengaruhi satu sama lain. ${ }^{2}$

Lingkungan merupakan faktor utama, yang memengaruhi kesehatan dan perilaku. ${ }^{2}$ Perubahan lingkungan memengaruhi fungsi hidung. Revolusi industri membawa kita pada pajanan berbagai macam polutan lingkungan, termasuk asap dan debu. Berbagai kebiasaan (merokok, konsumsi alkohol, dan penggunaan substansi intranasal seperti kokain) menjadi penyebab tambahan. ${ }^{4}$

Hidung merupakan organ penting, yang seharusnya mendapat perhatian lebih. Hidung mempunyai beberapa fungsi yaitu sebagai jalan nafas, pengatur kondisi udara, penyaring dan pelindung, indra penciuman, resonansi suara, proses bicara, dan refleks nasal. ${ }^{4}$ Karena posisinya yang terdapat di tengah wajah, hidung mudah terkena trauma. Kelainan hidung dan sinus disebabkan oleh proses inflamasi, akibat penyakit sistemik, atau kondisi yang memengaruhi secara sekunder. ${ }^{5}$

Data dari Departemen Kesehatan Republik Indonesia (DEPKES RI) tahun 2003 menyebutkan bahwa penyakit hidung dan sinus berada pada urutan ke-25 dari 50 pola penyakit peringkat utama atau sekitar 102.817 penderita rawat jalan di rumah sakit terhitung dari anak-anak sampai dewasa. $^{6}$ Berdasarkan penelitian yang dilaksanakan pada tahun 2012 di poliklinik THT-KL RSUP Prof. Dr. R. D. Kandou Manado jumlah kunjungan pada tahun 2012 sebanyak 2.305 orang. Sinusitis maksilaris, rinitis alergi, dan rinitis kronik termasuk dalam 10 penyakit terbanyak. ${ }^{7}$

Masalah kesehatan pada remaja dapat disebabkan oleh pubertas, perkembangan psikososial, dan akibat penyakit tertentu. Remaja khususnya siswa-siswi memerlukan perhatian khusus pada perubahan fisik dan psikologis yang terjadi. ${ }^{5}$ Bila siswasiswi mengalami gangguan kesehatan, maka dalam melakukan aktivitas akan mengalami berbagai hambatan, sehingga hasilnya menjadi tidak optimal. ${ }^{8}$ Siswasiswi SMP merupakan kelompok remaja produktif yang dapat terkena berbagai pajanan lingkungan sehingga memengaruhi kondisi kesehatan hidung. Penelitian ini bertujuan untuk mengetahui kesehatan hidung pada siswa-siswi SMP Negeri 4 Pineleng.

\section{METODE PENELITIAN}

Jenis penelitian ini ialah deskriptif observasional dengan desain potong lintang. Penelitian dilakukan pada 10 Oktober 2016 di SMP Negeri 4 Pineleng. Populasi penelitian ialah siswa-siswi SMP Negeri 4 Pineleng. Responden penelitian ialah siswasiswi kelas IX A SMP Negeri 4 Pineleng. Variabel penelitian diantaranya jenis kelamin, kavum nasi, konka, mukosa, sekret, septum, dan postnasal drips. Pemeriksaan hidung responden dilakukan secara langsung. Data hasil pemeriksaan dimasukkan pada tabel pemeriksaan THT yang telah disusun dengan Microsoft Word dan data diolah menggunakan Microsoft Excel.

\section{HASIL PENELITIAN}

Penelitian dilaksanakan di kelas IX A SMPN 4 Pineleng dengan total siswa-siswi berjumlah 25 orang, terdiri dari 13 orang $(52 \%)$ siswa dan 12 orang siswi (48\%).

Tabel 1. Distribusi berdasarkan jenis kelamin siswa-siswi SMPN 4 Pineleng.

\begin{tabular}{ccc}
\hline Jenis kelamin & n & $(\boldsymbol{\%})$ \\
\hline Laki - Laki & 13 & 52 \\
Perempuan & 12 & 48 \\
Total & 25 & 100 \\
\hline
\end{tabular}

Pada penelitian didapatkan persentase usia terbanyak yaitu usia 14 tahun berjumlah 12 orang (48\%), diikuti oleh usia 15 tahun berjumlah 7 orang (28\%), dan usia 13 tahun berjumlah 6 orang (24\%). 
Tabel 2. Distribusi berdasarkan usia siswasiswi SMPN 4 Pineleng.

\begin{tabular}{ccc}
\hline Usia & $\mathbf{N}$ & $\mathbf{( \% )}$ \\
\hline 13 Tahun & 6 & 24 \\
14 Tahun & 12 & 48 \\
15 Tahun & 7 & 28 \\
Total & 25 & 100 \\
\hline
\end{tabular}

Pada penelitian didapatkan hasil kavum nasi yang lapang pada 22 orang (88\%), kavum nasi sempit pada 3 orang (12\%); tidak ditemukan kavum nasi dengan massa (Tabel 3).

Tabel 3. Distribusi keadaan kavum nasi pada siswa-siswi SMPN 4 Pineleng.

\begin{tabular}{ccccc}
\hline Kavum & \multicolumn{2}{c}{$\mathbf{N}$} & \multicolumn{2}{c}{$(\%)$} \\
\cline { 2 - 5 } nasi & Kanan & Kiri & Kanan & Kiri \\
\hline Lapang & 22 & 22 & 88 & 88 \\
Sempit & 3 & 3 & 12 & 12 \\
Massa & 0 & 0 & 0 & 0 \\
Total & 25 & 25 & 100 & 100 \\
\hline
\end{tabular}

Tabel 4. Distribusi keadaan konka pada siswasiswi SMPN 4 Pineleng.

\begin{tabular}{ccccc}
\hline \multirow{2}{*}{ Konka } & \multicolumn{2}{c}{$\mathbf{n}$} & \multicolumn{2}{c}{$(\%)$} \\
\cline { 2 - 5 } & Kanan & Kiri & Kanan & Kiri \\
\hline Normal & 21 & 21 & 84 & 84 \\
Edema & 0 & 0 & 0 & 0 \\
Hiperemis & 1 & 1 & 4 & 4 \\
Pucat & 0 & 0 & 0 & 0 \\
Hipertrofi & 0 & 1 & 0 & 4 \\
Pucat + & 2 & 2 & 8 & 8 \\
Hipertrofi & & & & \\
Edema + & & & & \\
Pucat + & 1 & 0 & 4 & 0 \\
Hipertrofi & & & & \\
Atrofi & 0 & 0 & $0 \%$ & $0 \%$ \\
Total & 25 & 25 & $100 \%$ & $100 \%$ \\
\hline
\end{tabular}

Pada penelitian didapatkan hasil konka normal pada 21 orang $(84 \%)$, konka pucat disertai hipertrofi pada 2 orang $(8 \%)$, konka hiperemis pada 1 orang (4\%), konka hipertrofi pada 1 orang (4\%) untuk hidung kiri, konka edema serta pucat dan hipertrofi pada 1 orang (4\%) untuk hidung kanan; tidak ditemukan konka yang edema, pucat, dan atrofi (Tabel 4).

Pada penelitian didapatkan hasil mukosa normal pada 22 orang (88\%), mukosa livide pada 2 orang $(8 \%)$ untuk hidung kiri dan 3 orang (12\%) untuk hidung kanan, mukosa hiperemis berjumlah 1 orang (4\%) pada hidung kiri (Tabel 5).

Tabel 5. Distribusi keadaan mukosa pada siswa-siswi SMPN 4 Pineleng.

\begin{tabular}{ccccc}
\hline \multirow{2}{*}{ Mukosa } & \multicolumn{2}{c}{$\mathbf{N}$} & \multicolumn{2}{c}{$(\%)$} \\
\cline { 2 - 5 } & Kanan & Kiri & Kanan & Kiri \\
\hline Normal & 22 & 22 & 88 & 88 \\
Hiperemis & 0 & 1 & 0 & 4 \\
Livide & 3 & 2 & 12 & 8 \\
Total & 25 & 25 & 100 & 100 \\
\hline
\end{tabular}

Pada penelitian didapatkan hasil tidak ditemukan sekret berjumlah 23 orang (92\%) pada hidung kiri dan 22 orang (88\%) pada hidung kanan, sekret serous berjumlah 2 orang $(8 \%)$ pada hidung kiri dan 3 orang (12\%) pada hidung kanan; tidak ditemukan sekret yang mukoid dan purulen (Tabel 6).

Tabel 6. Distribusi keadaan sekret pada siswasiswi SMPN 4 Pineleng.

\begin{tabular}{ccccc}
\hline \multirow{2}{*}{ Sekret } & \multicolumn{2}{c}{$\mathbf{N}$} & \multicolumn{2}{c}{$(\%)$} \\
\cline { 2 - 5 } & Kanan & Kiri & Kanan & Kiri \\
\hline Tidak ada & 22 & 23 & 88 & 92 \\
Serous & 3 & 2 & 12 & 8 \\
Mukoid & 0 & 0 & 0 & 0 \\
Purulen & 0 & 0 & 0 & 0 \\
Total & 25 & 25 & 100 & 100 \\
\hline
\end{tabular}

Pada penelitian didapatkan hasil septum normal berjumlah 24 orang $(96 \%)$ pada hidung kiri dan 25 orang (100\%) pada hidung kanan; septum deviasi berjumlah 1 orang (4\%) pada hidung kiri; tidak ditemukan septum dengan abses dan hematoma (Tabel 7).

Tabel 7. Distribusi keadaan septum pada siswa-siswi SMPN 4 Pineleng.

\begin{tabular}{ccccc}
\hline \multirow{2}{*}{ Septum } & \multicolumn{2}{c}{$\mathbf{N}$} & \multicolumn{2}{c}{$(\%)$} \\
\cline { 2 - 5 } & Kanan & Kiri & Kanan & Kiri \\
\hline Normal & 25 & 24 & 100 & 96 \\
Deviasi & 0 & 1 & 0 & 4 \\
Abses & 0 & 0 & 0 & 0 \\
Hematoma & 0 & 0 & 0 & 0 \\
Total & 25 & 25 & 100 & 100 \\
\hline
\end{tabular}

Pada penelitian didapatkan hasil post 
nasal drip negatif pada 24 orang $(96 \%)$ dan post nasal drip positif pada 1 orang (4\%).

Tabel 8. Distribusi keadaan post nasal drip pada siswa-siswi SMPN 4 Pineleng.

\begin{tabular}{ccccc}
\hline Post nasal & \multicolumn{2}{c}{$\mathbf{n}$} & \multicolumn{2}{c}{$(\boldsymbol{\%})$} \\
\cline { 2 - 5 } drip & Kanan & Kiri & Kanan & Kiri \\
\hline Ada & 1 & 1 & $4 \%$ & $4 \%$ \\
Tidak Ada & 24 & 24 & $96 \%$ & $96 \%$ \\
Total & 25 & 25 & $100 \%$ & $100 \%$ \\
\hline
\end{tabular}

\section{BAHASAN}

Penelitian kesehatan hidung siswasiswi SMP Negeri 4 Pineleng yang melibatkan siswa-siswi kelas IX A dengan total responden sebanyak 25 orang. Didapatkan hasil karakteristik responden terbanyak berjenis kelamin laki-laki (52\%) dan sisanya ialah perempuan (48\%). Karakteristik usia terbanyak pada penelitian ini ialah 14 tahun (48\%) dan sisanya berusia 15 tahun (28\%) dan berusia 13 tahun (24\%).

Pada pemeriksaan didapatkan hasil sebagian besar kavum nasi yang lapang (88\%) sedangkan lainnya kavum nasi yang sempit (12\%). Kavum nasi dapat menjadi sempit disebabkan oleh banyak penyebab, salah satunya ialah polip nasi. Polip nasi ialah massa lunak yang mengandung banyak cairan di dalam rongga hidung, berwarna putih keabu-abuan, yang terjadi akibat inflamasi mukosa. Polip dapat timbul pada laki-laki ataupun perempuan dari usia anak-anak sampai usia lanjut. ${ }^{9}$ Polip nasi biasanya timbul setelah anak berumur lebih dari 2 tahun dan jarang terjadi pada anak yang berusia kurang dari 10 tahun. $^{10-12}$

Penelitian yang dilakukan oleh Maramis $^{13}$ mengenai kesehatan hidung pada siswa-siswi Sekolah Dasar Negeri 11 Manado dan penelitian yang dilakukan oleh Legoh $^{14}$ mengenai kesehatan hidung siswa Sekolah Dasar Inpres 10/73 Pandu menunjukkan sebesar $100 \%$ responden memiliki kavum nasi yang normal. Berbeda dengan penelitian yang dilakukan oleh Polii $^{15}$ mengenai kesehatan hidung siswa SMA Negeri 9 Binsus Manado menunjukkan 5,72\% memiliki kavum nasi dengan massa dan 2,85\% memiliki kavum nasi yang sempit. Hal ini memiliki kesamaan dengan hasil penelitian yang dilakukan pada siswa-siswi kelas IX A SMPN 4 Pineleng, yaitu didapatkan hasil kavum nasi yang sempit dengan persentase $12 \%$.

Pada pemeriksaan didapatkan hasil sebagian besar konka normal dengan persentase $84 \%$ pada hidung kanan dan kiri. Keadaan abnormal yang bervariasi ditemukan pada konka kanan dan kiri. Konka pucat disertai hipertrofi merupakan keadaan abnormal terbanyak pada konka dengan persentase $8 \%$ pada kedua bagian hidung. Keadaan abnormal lain yang ditemukan ialah konka hiperemis dengan persentase $4 \%$ pada kedua bagian hidung. Konka hipertrofi merupakan keadaan abnormal pada konka kiri dengan persentase $4 \%$ dan konka edema disertai pucat dan hipertrofi merupakan keadaan abnormal pada konka kanan dengan persentase $4 \%$.

Penelitian yang dilakukan oleh Legoh $^{14}$ mengenai kesehatan hidung siswa Sekolah Dasar Inpres 10/73 Pandu menunjukkan $5,56 \%$ memiliki konka hiperemis. ${ }^{14}$ Hal ini memiliki kesamaan dengan hasil penelitian ini yaitu didapatkan hasil konka hiperemis dengan persentase $4 \%$. Konka yang edema merupakan suatu gejala penyakit hidung berupa penumpukan atau akumulasi cairan di luar pembuluh darah karena meningkatnya cairan pada hidung. Konka yang hiperemis terjadi karena vasodilatasi kapiler-kapiler pada hidung akibat proses inflamasi. ${ }^{16}$ Konka dapat menjadi edema dan hiperemis disebabkan oleh banyak penyebab, salah satunya adalah rinitis vasomotor.

Rinitis vasomotor adalah suatu keadaan idiopatik yang didiagnosis tanpa adanya infeksi, alergi, eosinofilia, perubahan hormonal dan pajanan obat. Etiologi dan patofisiologi dari rinitis vasomotor belum diketahui secara pasti. ${ }^{17}$

Konka dapat terlihat pucat dikarenakan banyak mengandung cairan sehingga sedikit aliran darah yang masuk. Penyebab konka hipertrofi ialah rinitis alergi, rinitis 
vasomotor, dan kompensasi dari septum deviasi kontralateral. ${ }^{16}$ Rinitis hipertrofi dan rinitis medikamentosa juga dapat memperlihatkan konka hipertrofi.

Rinitis hipertrofi adalah perubahan mukosa hidung pada konka inferior yang mengalami hipertrofi karena proses inflamasi kronis oleh infeksi bakteri primer atau sekunder. Konka inferior dapat juga mengalami hipertrofi tanpa terjadi infeksi bakteri, misalnya sebagai lanjutan dari rinitis alergi dan vasomotor. ${ }^{18}$

Rinitis medikamentosa adalah suatu kelainan hidung berupa gangguan respons normal vasomotor yang diakibatkan oleh pemakaian vasokonstriktor topikal dalam waktu lama dan berlebihan, sehingga menyebabkan sumbatan hidung yang menetap. ${ }^{17}$ Rinitis medikamentosa dapat terjadi pada laki-laki dan perempuan, tetapi lebih sering terjadi pada orang dewasa muda dan setengah baya. Selain itu, kelainan yang bisa terjadi pada konka ialah atrofi. Atrofi pada konka dapat terjadi pada rinitis atrofi. Rinitis atrofi merupakan infeksi hidung kronik, yang ditandai oleh adanya atrofi progresif pada mukosa dan tulang konka. ${ }^{18}$

Pada penelitian ini didapatkan hasil sebagian besar mukosa normal dengan persentase $88 \%$. Mukosa livide merupakan keadaan abnormal terbanyak pada mukosa dengan persentase $12 \%$ pada hidung kanan dan $8 \%$ pada hidung kiri. Keadaan abnormal lain yang ditemukan ialah mukosa hiperemis dengan persentase $4 \%$ pada hidung sebelah kiri. Mukosa livide atau pucat terjadi karena banyak cairan pada mukosa sehingga menyebabkan aliran darah ke mukosa menjadi sedikit. ${ }^{19}$ Mukosa dapat menjadi livide disebabkan oleh banyak penyebab, salah satunya adalah rinitis alergi.

Rinitis alergi adalah penyakit inflamasi yang disebabkan oleh reaksi alergi pada pasien atopi yang sebelumnya sudah tersensitasi dengan alergen yang sama serta dilepaskannya suatu mediator kimia ketika terjadi paparan ulang dengan alergen spesifik. $^{20}$

Pada anak, rinitis alergi lebih sering terjadi pada anak laki-laki dari pada anak perempuan, tetapi pada orang dewasa, prevalensinya kira-kira sama antara lakilaki dan perempuan. ${ }^{21}$ Rinitis mungkin lebih umum pada orang dewasa dibandingkan pada anak-anak. ${ }^{22}$

Penelitian yang dilakukan oleh Reinhard mengenai rinitis alergi di Poliklinik THT-KL BLU RSU Prof. Dr. R. D. Kandou Manado periode Januari 2010 Desember 2012 menunjukkan jumlah kasus rinitis alergi sebanyak $209(1,61 \%)$ kasus dari 12.981 jumlah pengunjung. Kelompok usia 21-30 tahun merupakan kelompok usia terbanyak yang didominasi oleh perempuan. $^{23}$ Penelitian yang dilakukan oleh Polii mengenai kesehatan hidung siswa SMA Negeri 9 Binsus Manado menunjukkan $11,42 \%$ memiliki mukosa livide. ${ }^{15}$ Hal ini memiliki sejalan dengan hasil penelitian yang dilakukan pada siswasiswi kelas IX A SMPN 4 Pineleng, yaitu didapatkan hasil mukosa livide dengan persentase $8 \%$ pada hidung kiri dan $12 \%$ pada hidung kanan.

Mukosa hiperemis terjadi pada keadaan inflamasi seperti rinitis yang disebabkan oleh infeksi, alergi atau iritasi. ${ }^{24}$ Penelitian yang dilakukan oleh Legoh $^{14}$ di Sekolah Dasar Inpres 10/73 Pandu menunjukkan sebesar $11,11 \%$ memiliki mukosa hiperemis sedangkan penelitian yang dilakukan oleh Polii $^{15}$ mengenai kesehatan hidung siswa SMA Negeri 9 Binsus Manado menunjukkan 5,72\% memiliki mukosa hiperemis. Hal ini memiliki kesamaan dengan hasil penelitian yang dilakukan pada siswa-siswi kelas IX A SMPN 4 Pineleng, yaitu didapatkan mukosa hiperemis dengan persentase $4 \%$ pada hidung kiri.

Pada penelitian ini, hasil pemeriksaan sekret mendapatkan sebagian besar tidak terdapat sekret dengan persentase 92\% pada hidung sebelah kiri dan $88 \%$ pada hidung sebelah kanan. Keadaan abnormal lain yang ditemukan ialah sekret serous pada hidung sebelah kiri (8\%) dan sebelah kanan (12\%). Sekret serous merupakan sekret hidung yang bersifat encer terutama timbul pada rinitis alergi dan vasomotor. 
Jenis sekret ini terdiri atas protein pembuluh darah yang bocor dari pembuluh darah yang permeabel dan sering terjadi pada kasus alergi. Sekret mukoid dapat terjadi karena aktivitas yang berlebihan dari sel goblet. Sekret purulen merupakan sekret yang bersifat kental, putih kekuningan dan kadang berbau busuk dapat disebabkan oleh banyak penyebab, salah satunya ialah sinusitis. ${ }^{25}$

Sinusitis adalah proses peradangan pada mukosa sinus paranasal. ${ }^{26}$ Sinusitis lebih sering terjadi pada musim dingin daripada musim panas. $^{27}$ Data dari DEPKES RI tahun 2003 menyebutkan bahwa penyakit sinusitis berada dalam urutan ke-25 dari 50 pola penyakit peringkat utama atau sekitar 102.817 penderita rawat jalan di rumah sakit. ${ }^{28}$

Pada penelitian ini, hasil pemeriksaan septum mendapatkan sebagian besar normal dengan persentase $100 \%$ pada hidung sebelah kanan dan $96 \%$ pada hidung sebelah kiri. Keadaan abnormal lain yang ditemukan ialah deviasi pada septum dengan persentase $4 \%$ pada hidung sebelah kiri.

Septum deviasi adalah septum nasi yang tidak terletak lurus di tengah rongga hidung. Secara umum, beberapa etiologi dari septum deviasi adalah kongenital, genetik, trauma, infeksi, bahkan efek dari massa pada neoplasma kavum nasi. ${ }^{29}$

Hasil penelitian yang dilakukan oleh Maramis $^{13}$ mengenai kesehatan hidung pada siswa-siswi Sekolah Dasar Negeri 11 Manado dan yang dilakukan oleh Legoh ${ }^{14}$ mengenai kesehatan hidung siswa Sekolah Dasar Inpres 10/73 Pandu menunjukkan sebesar $100 \%$ responden memiliki septum yang normal. Berbeda dengan penelitian yang dilakukan oleh Polii ${ }^{15}$ mengenai kesehatan hidung siswa SMA Negeri 9 Binsus Manado menunjukkan 11,42\% memiliki septum deviasi pada hidung kanan. Hal ini sejalan dengan hasil penelitian yang dilakukan pada siswa-siswi kelas IX A SMPN 4 Pineleng, yaitu didapatkan hasil septum deviasi sebesar $4 \%$ pada hidung kiri.

Pada penelitian ini post nasal drip tidak ditemukan pada sebagian besar $(96 \%)$ responden. Post nasal drip adalah akumulasi lendir di belakang hidung dan memberikan sensasi lendir menurun dari belakang hidung menuju tenggorokan yang dapat disebabkan oleh sekresi yang berlebihan atau kental, dan gangguan dalam pembersihan lendir dari hidung dan tenggorokan. Post nasal drip dapat disebabkan oleh berbagai penyebab, salah satunya ialah rinitis kronis. ${ }^{4,25,26}$

Penelitian yang dilakukan oleh Maramis $^{13}$ mengenai kesehatan hidung pada siswa-siswi Sekolah Dasar Negeri 11 Manado menunjukkan $12 \%$ terdapat post nasal drip pada hidung kanan dan $8 \%$ pada hidung kiri. Hal ini serupa dengan hasil penelitian yang dilakukan pada siswa-siswi kelas IX A SMPN 4 Pineleng, yaitu didapatkant post nasal drip sebanyak $4 \%$.

\section{SIMPULAN}

Berdasarkan hasil penelitian dan bahasan dapat disimpulkan bahwa sebagian besar siswa-siswi SMPN 4 Pineleng mempunyai kesehatan hidung yang baik.

\section{SARAN}

Perlu dilakukan upaya promotif mengenai kesehatan hidung oleh pemerintah untuk meningkatkan kesehatan hidung khususnya pada anak sekolah.

Perlu dilakukan penelitian lebih lanjut mengenai kesehatan hidung terutama pada anak sekolah, agar bisa mendeteksi lebih dini masalah kesehatan hidung.

Perlu dilakukan pemeriksaan lanjutan bagi responden yang memiliki masalah kesehatan hidung kepada dokter spesialis THT-KL agar memperoleh penanganan sedini mungkin dan mencegah keadaan yang bisa memperparah masalah hidung yang terjadi.

\section{DAFTAR PUSTAKA}

1. World Health Organization. Promoting mental health; Concepts, emerging evidence, practice; a report of the World Health Organization, Department of Mental Health and Substance Abuse in collaboration 
with the Victorian Health Promotion Foundation and the University of Melbourne. World Health Organization. Geneva, 2005.

2. Maulana H. Promosi Kesehatan. Jakarta: EGC, 2009; p. 5.

3. Azikin N. Profil kesehatan Kota Makassar. Dinas Kesehatan Kota Makassar, 2008; p. 55-8.

4. Hilger PA. Hidung: Anatomi dan fisiologi terapan. In: Adams GL, Boies LR, Higler PA, editors. Boies Buku Ajar Penyakit THT (6th ed). Jakarta: EGC, 1997; p. 173.

5. Goldsmith AJ. THT Remaja. In: Lucente FE, Har-El G, editors. Ilmu THT Esensial (5th ed). Jakarta: EGC, 2011; p. 573.

6. HTA Indonesia. Functional endoscopic sinus surgery di Indonesia (homepage on the internet). 2006. [cited 20 Agustus 2015]. Available from: http://buk.depkes.go.id/index.php

7. Paembobo EEB. Pola penyakit pasien rawat jalan di poliklinik Telinga Hidung Tenggorokan-Bedah Kepala Leher BLU RSU Prof. Dr. R. D. Kandou-Manado periode Januari 2010-Desember 2012 [Skripsi]. Manado: Fakultas Kedokteran Universitas Sam Ratulangi; 2013.

8. Lutan R. Pendidikan Kesehatan. Jakarta: Depdiknas, 2000.

9. Mangunkusumo E, Wardani RS. Polip Hidung. In: Soepardi EA, Iskandar N, Bashiruddin J, Restuti RD. editors. Telinga Hidung Tenggorok Kepala \& Leher (7th ed). Jakarta: FKUI, 2012; p. 101-3.

10.Bernstein JM. Chronic rhinosinusitis with and without nasal polyposis. In: Sinusitis from Microbiology to Management. New York: Taylor and Francis, 2006; p. 375-80.

11.Iloba N. Nasal polyps. March 2009. [cited November 2016]. Available from www.thestethoscope.org.

12.Al-Mazrou KA, Bukhari M, Al-Fayez AI. Characteristics of antrochoanal polyps in the pediatric age group. Annals of Thoracic Medicine. 2009;4(3):133-6.

13.Maramis FGA. Kesehatan hidung pada siswa-siswi Sekolah Dasar Negeri 11 Manado [Skripsi]. Manado: Fakultas
Kedokteran Universitas Sam Ratulangi; 2015.

14.Legoh AM. Kesehatan hidung siswa Sekolah Dasar INPRES 10/73 Pandu [Skripsi]. Manado: Fakultas Kedokteran Universitas Sam Ratulangi; 2015.

15.Poli C. Kesehatan hidung siswa SMA Negeri 9 Binsus Manado [Skripsi]. Manado: Fakultas Kedokteran Universitas Sam Ratulangi; 2015.

16.Former SEJ, Eccles R. Chronic inferior turbinate enlargement and implications for surgical intervention. Rhinology. 2006;44:234-8.

17.Irawati N, Poerbonegoro NL, Kasakeyan E. Rinitis vasomotor. In: Soepardi E A, Iskandar N, Bashiruddin J, Restuti RD, editors. Telinga Hidung Tenggorok Kepala \& Leher (7th ed). Jakarta: FKUI, 2012; p. 113-5.

18. Wardani RS, Mangunkusumo E. Infeksi hidung. In: Soepardi EA, Iskandar N, Bashiruddin J, Restuti RD. editors. Telinga Hidung Tenggorok Kepala \& Leher (7th ed). Jakarta: FKUI, 2012; p. 116-21.

19.Lund VJ. Acute and chronic nasal disorders. In: Ballenger's Otorhinolaryngology Head and Neck Surgery (16th ed). Ontario: BC, Decker Inc, 2003; p. 748-66.

20.Nagel P, Gurkov R. Hidung dan sinus paranasal. In: Nagel P, Gurkov R. editors. Dasar-Dasar Ilmu THT (2nd ed). Jakarta: EGC, 2012; p. 38-9.

21.Sheikh J, Najib U. Allergic rhinitis. 2015 Feb 16 [cited 2016 Oct 23]. Available from: http://emedicine.medscape. com/article/134825-overview\#a1

22.Rhinitis: Synopsis. [cited 2016 Oct 23]. Available from: http: //www.worldallergy.org/educationand-programs/education/allergicdisease-resource-center/ professionals/rhinitis-synopsis\#

23. Reinhard E. Rinitis alergi di Poliklinik THT-KL BLU RSU Prof. Dr. R. D. Kandou Manado periode Januari 2010-Desember 2012 [Skripsi]. Manado: Fakultas Kedokteran Universitas Sam Ratulangi; 2013.

24.Lund VJ. Acute and chronic nasal disorders. In: Ballenger's Otorhinolaryngology Head and Neck 
Surgery (16th ed). Ontario: BC, Decker Inc, 2003; p. 748-66.

25.Suryadi ME. Sinusitis. 2014 [cited 2016 Oct 23]. Available from: http://repository.usu.ac.id/bitstream/1 23456789/39684/4/Chapter\%20II.pdf

26. Nagel P, Gurkov R. Hidung dan sinus paranasal. In: Nagel P, Gurkov R. editors. Dasar-Dasar Ilmu THT (2nd ed). Jakarta: EGC, 2012; p. 42-3.

27. Brook I, Riauba L, Benson BE. Acute Sinusitis. 2016 May 06 [cited 2016 Oct 23]. Available from: http://emedicine.medscape.com/articl e/232670-overview\#a6
28.Paramasivan KM. Gambaran penderita sinusitis maksila dengan infeksi gigi rahang atas di RSUP Haji Adam Malik Medan. 2012. [cited 2016 Oct 23] Available from: http://repository.usu.ac.id/bitstream/1 23456789/31193/5/Chapter\%20I.pdf

29.Aziz T, Biron VL, Ansari K, Flores-Mir C. Measurement tools for the diagnosis of nasal septal deviation: a systematic review. Edmonton: Department of Surgery, Division of Otolaryngology-Head and Neck Surgery, University of Alberta, 2014. 